throughout the programming period films and additional talks were scheduled in Kingston as well as in Providence.

However, complications soon appeared.

Security of valuable items was absolutely essential. Exhibition space in the URI Library is available in the form of a few glass cases only, providing no security whatsoever.

Temperature control was another important consideration; without the guarantee of proper temperature control and tight security no institution would ever allow their artifacts to be displayed at another institution. Therefore, the major exhibit had to be scheduled at the URI Fine Arts Center and a smaller and less costly showing at the URI Library was consequently added to the program.

Long term scheduling was necessary for the contributors but impossible to manage on the tentative basis of a grant proposal.

Time for coordination, writing and making the arrangements was considerable. This was difficult for all the planners and consultants and I could not, however, obtain a guarantee from the URI Library that if the project were funded I would even get release time to carry the program to completion. It became clearer as the preliminary planning advanced that even if the planning grant were approved, the situation could easily get out of hand.

Release time difficulties, remuneration problems, lack of real support from my department and the slowness of the University and state bureaucra- cies to move and to react to the inevitable alterations in long-range planning (in such areas as scheduling and disbursement of funds, for example) could create impossible log-jams in the few months between funding approval and the program opening. Thus, though it pains me to say so, I must admit when the planning grant was rejected, I was relieved.

In retrospect, I realized why so few academic libraries have done this sort of public programming: the obstacles inherent in the university system can be simply overwhelming in light of all the paperwork and preparations involved with obtaining funding even at the planning stages. In my experience, participants spent considerable amounts of their own time and money during the lengthy and involved process of roughing out the program and preparing a formal grant application. Faculty consultants within the University have to be convinced to add to their workloads with no added monetary compensation, and the "catch-22" of uncertainty of release time (made even more uncertain by the staff shortages prevalent nowadays) must be faced. And, of course, bureaucratic inertia must be overcome or outmaneuvered.

I think a realistic approach to what one's involvement may entail could be helpful and I hope my experiences will serve as an example of some of the problems which, if unavoidable, can at least be identified in advance and accommodated.

\title{
ACRL 1983/84 Budget
}

At its June 1983 meeting, the ACRL Board approved the 1983/84 budget. Highlights for the budget year include:

-the extension of the Bibliographic Liaison Project for another year;

- the purchase of a terminal with a view to ACRL participation in the ALANET electronic mail and database program;

- the continuation of the ACRL Jobline, Fast Job Listing Service, and ACRL 100 Libraries Project;

-increased levels of support for ACRL committees, chapters, and sections;

-the Third ACRL National Conference in Seattle;

- a preconference for the Rare Books and Manuscripts Section to be held in Austin, Texas;

- a balanced budget for the Continuing Education program;

-ACRL staff support for the J. Morris Jones leadership project award;

-a $\$ 3,000$ subsidy to ALA Publishing to underwrite the publication costs of the next Publication in Librarianship Series monograph;

- support for newsletters for the Bibliographic
Instruction Section, the Rare Books and Manuscripts Section, and the Western European Specialists Section;

- a budget for Choice which exceeds $\$ 1$ million for the first time;

- the transfer of advertising activities for $C \mho R L$ and $C \& R L$ News to Choice with the expectation of increased revenues as a result;

- the offering of three NEH workshops in cooperation with the Public Libraries Association during the next year.

The 1982/83 fiscal year showed a strong performance by all ACRL programs, although the total continuing education program (revenues and expenses) was smaller than planned. Revenues were slightly under budget, but this was offset by significant savings achieved in expenses. ACRL added $\$ 42,500$ and Choice added $\$ 90,300$ to their respective fund balances.

The budget for 1983/84 is presented first in summary form and then in more detail, grouped by the four categories:

-membership dues and activities;

-publications; 
- conferences and workshops;

-other.

Pie charts for revenues and expenses in these cate- gories provide a quick overview of ACRL's projected sources and uses of funds for the 1983/84 year.

ACRL Summary Budget

\begin{tabular}{|c|c|c|c|}
\hline Item & $\begin{array}{c}1982 / 83 \\
\text { Budgeted }\end{array}$ & $\begin{array}{c}1982 / 83 \\
\text { Actual }\end{array}$ & $\begin{array}{c}1983 / 84 \\
\text { Budgeted }\end{array}$ \\
\hline $\begin{array}{l}\text { Revenues } \\
\text { Expenses }\end{array}$ & $\begin{array}{r}\$ 1,482,176 \\
1,459,537 \\
\end{array}$ & $\begin{array}{r}\$ 1,467,375 \\
1,362,277 \\
\end{array}$ & $\begin{array}{r}\$ 1,800,102 \\
1,760,847 \\
\end{array}$ \\
\hline Net Income & 22,639 & 105,098 & 39,255 \\
\hline $\begin{array}{l}\text { Balance Per Books } \\
\text { Deferred Liabilities }\end{array}$ & $\begin{array}{r}56,657 \\
312,400 \\
\end{array}$ & $\begin{array}{l}184,020 \\
254,000 \\
\end{array}$ & \\
\hline Operating Balance & $\$ 369,057$ & $\$ 438,020$ & $\$ 477,275$ \\
\hline
\end{tabular}

\section{REVENUES}

\begin{tabular}{|c|c|c|c|c|}
\hline Activity & $\begin{array}{c}1 \\
\text { Budgeted } \\
1982 / 83\end{array}$ & $\begin{array}{c}2 \\
\text { Actual } \\
1982 / 83\end{array}$ & $\begin{array}{c}3 \\
\text { Budgeted } \\
1983 / 84\end{array}$ & $\begin{array}{c}4 \\
\text { Difference } \\
3-2\end{array}$ \\
\hline Membership Dues & $\$ 193,400$ & $\$ 202,145$ & $\$ 199,800$ & $\$ \quad(2,345)$ \\
\hline \multicolumn{5}{|l|}{ Publications } \\
\hline Choice & 935,999 & 944,697 & $1,000,042$ & 55,345 \\
\hline$C \mho R L$ & 110,225 & 101,917 & 113,199 & 11,282 \\
\hline$C \triangleleft R L$ News & 74,709 & 78,556 & 84,645 & 6,089 \\
\hline Publications, In-House & 18,600 & 19,924 & 20,000 & 76 \\
\hline Fast Job Listing Service & 2,850 & 4,285 & 2,500 & $(1,785)$ \\
\hline Subtotal & $\$ 1,142,383$ & $\$ 1,149,379$ & $\$ 1,220,386$ & $\$ 71,007$ \\
\hline \multicolumn{5}{|l|}{ Conferences \& Workshops } \\
\hline National Conf., Seattle & - & - & 200,000 & 200,000 \\
\hline Continuing Education & 40,500 & 20,195 & 35,000 & 14,805 \\
\hline Preconferences & 39,670 & 36,983 & 25,585 & $(11,398)$ \\
\hline NEH Project* & 62,423 & 55,213 & 104,731 & 49,518 \\
\hline J. Morris Jones BI Workshops & - & - & 5,000 & 5,000 \\
\hline J. Morris Jones Leadership & - & - & 5,000 & 5,000 \\
\hline Subtotal & $\$ 142,593$ & $\$ 112,391$ & $\$ 375,316$ & $\$ 262,925$ \\
\hline Other-Including Jobline & 3,800 & 3,460 & 4,600 & 1,140 \\
\hline TOTAL & $\$ 1,482,176$ & $\$ 1,467,375$ & $\$ 1,800,102$ & $\$ 332,727$ \\
\hline
\end{tabular}

${ }^{*}$ One-half of total grant, $\$ 209,463$. Grant is for two-year project. 


\section{EXPENSES}

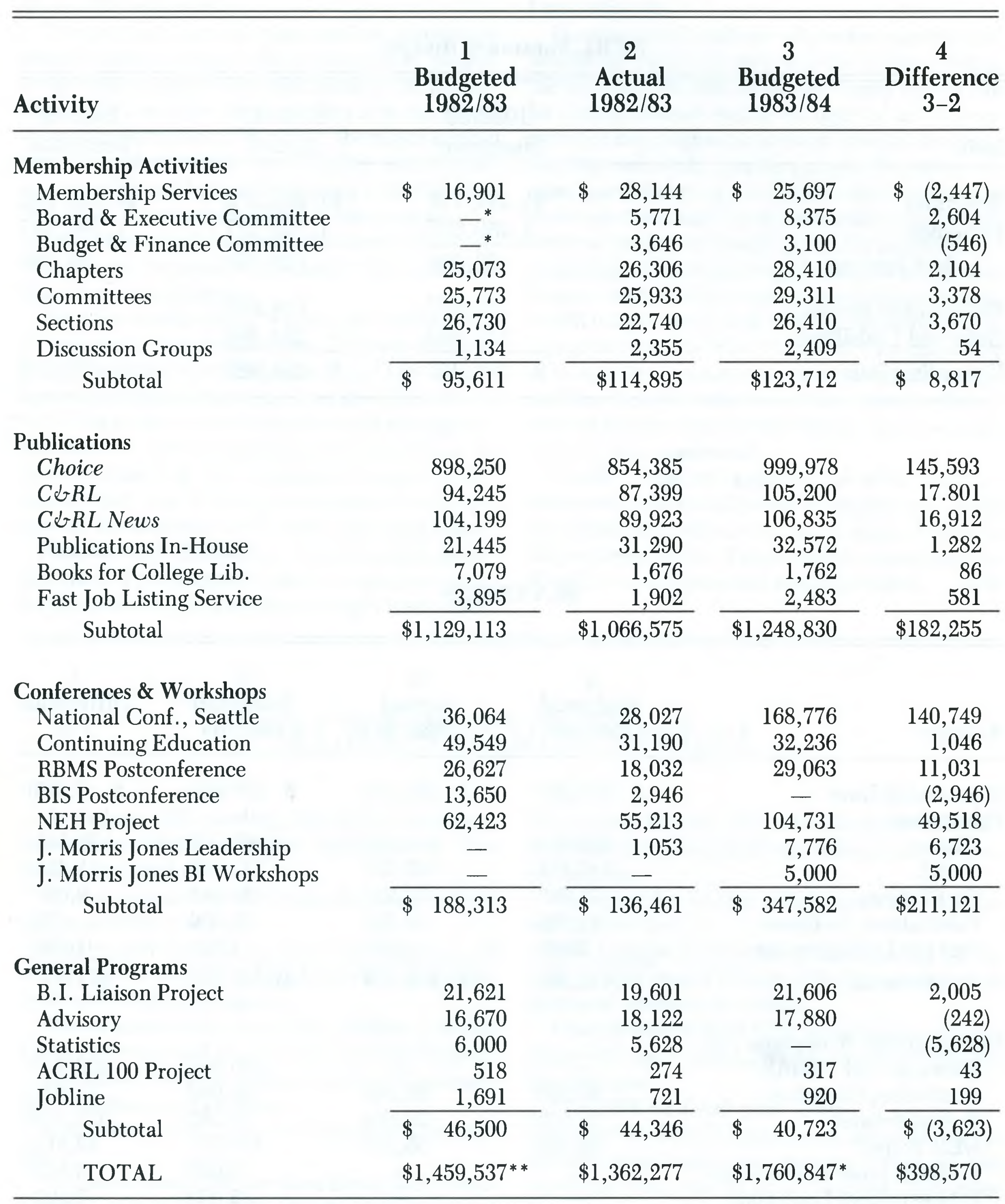

${ }^{*}$ Expenses not broken out separately.

${ }^{* *} \mathrm{~A} \$ 40,000$ budgeted reserve is not included. 


\section{REVENUES}
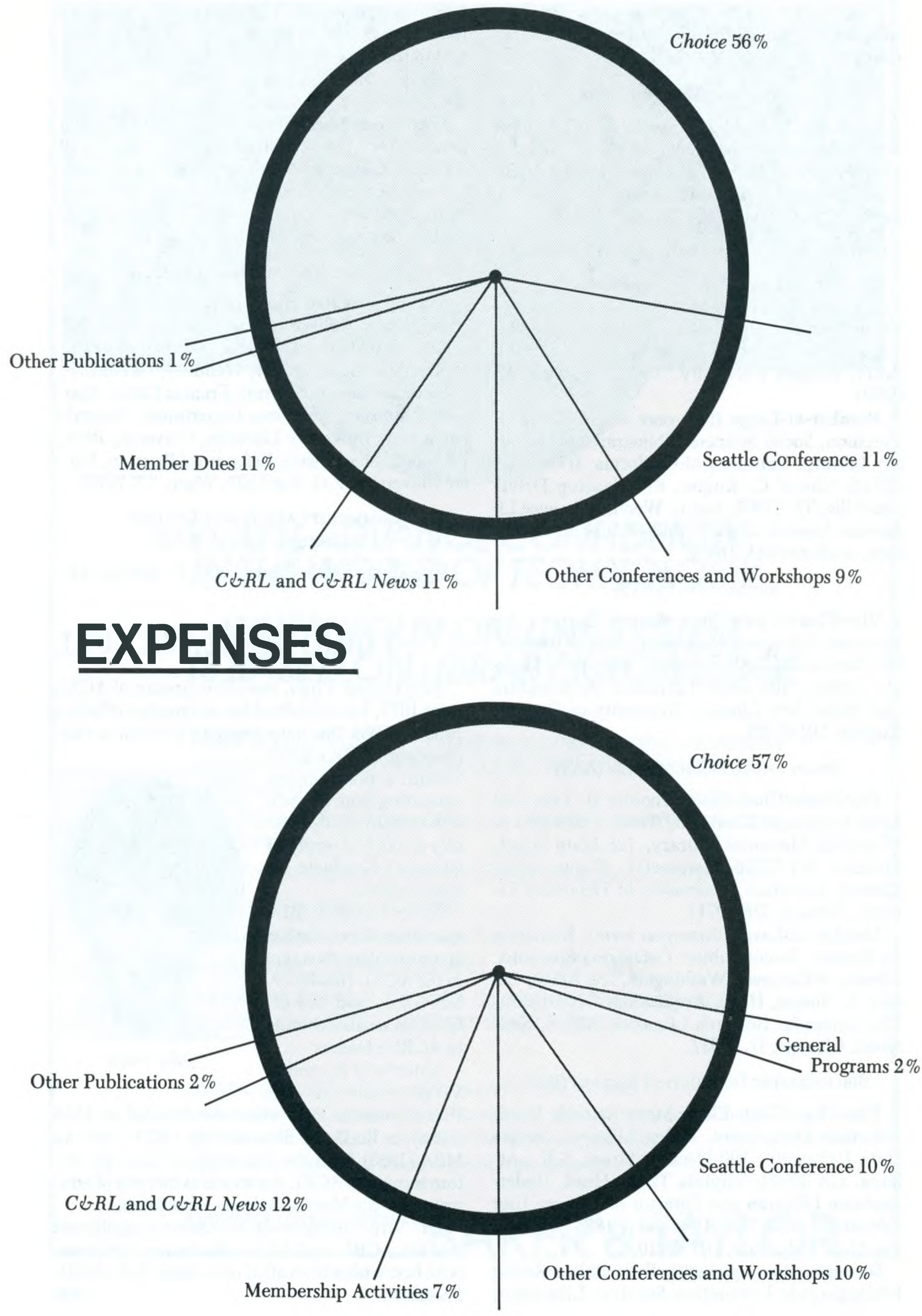